\title{
Fabrication and erroneous information
}

\section{Exploring two types of news media scandals as critical incidents in journalism}

MARK BLACH-ØRSTEN

Roskilde University

JANNIE MøLLER HARTLEY

Roskilde University

MARIA BENDIX WITTCHEN

Roskilde University

\section{Abstract}

This article analyzes news media scandals as critical incidents in journalism. A critical incident can be broadly understood as an event or development that reflects 'the hows and whys' of journalism. A part of the research into critical incidents studies these as occurrences that are made scandalous by journalistic misdeeds or ethical lapses. The purpose of this article is twofold: first, theoretically, to link this understanding of critical incidents to the study and theory of the scandal. Second, empirically, to analyze how different types of news media scandals lead to reflection and debate about journalism. To achieve this purpose, the article focuses on two specific types of news media scandals: the fabrication scandal and the erroneous information scandal. The two types of scandals bring into question fundamental standards and practices of journalism, such as 'telling the truth' and basing stories on 'facts.' They also lead to reflections on 1) increased competition between news media, 2) the pressure to produce more stories inside the individual newsroom, 3) the drive to 
get a 'scoop,' 4) journalism's relationship to powerful and/or anonymous sources, and 5) the problems of a 'trust, not supervise' culture in the newsroom.

\section{KEYWORDS}

journalism, scandal, critical incident, fabrication

\section{Introduction}

News media scandals occur in many different countries and often become global news stories when they are uncovered. In the US, both the Stephen Glass scandal (1998) and the Jayson Blair scandal (2003) involved reporters who were caught fabricating or plagiarizing their stories. In Great Britain, Sky News reporter James Furlong fabricated a news story that showed a fake live firing of a cruise missile at sea in the Persian Gulf during the Iraq War in 2003. In 2011, the British Tabloid News of World had to shut down due to a phonehacking scandal. The latest global media scandal to hit the headlines is the so-called 'Spiegel-gate' (2018). A prizewinning reporter of the famous German news magazine was caught fabricating both stories and sources. Historically, of course, various kinds of news media scandals have always existed with the Moon Hoax, a series of six articles about the people living on the moon, published by New York Sun in 1835, often referenced as one of the first news media scandals (Thornton, 2000).

Traditionally, the news media is a central part of the scandalization process: from Watergate to the Panama Papers, many types of scandals are linked to information uncovered by the news media. However, journalists and news media also sometimes find themselves the subject of scandals (Lasorsa \& Dai, 2007: Fenton, 2019; Kepplinger \& Viererbl, 2021). Historically, there has been a link between the study of 'scandalous' journalism and the study of critical incidents in journalism (D'Angelo, 2021). While a critical incident can be broadly described as "an event or development that leads journalists to reconsider 'the hows and whys of journalism practice'" (Jenkins et al., 2021: 1), D'Angelo (2021) shows how the concept of the critical incident has also been linked to paradigm repair research since the 
1980s. In this line of research, according to D'Angelo (2021: 19): "(...) a critical incident is incited by an occurrence made scandalous by virtue of journalistic misdeeds and/or ethical lapses that news media must subsequently promote as an accident."

In a recent book by Tandoc et al. (2021), the concept of the critical incident is presented as an entrance point for the discussion on the changes and challenges that journalism as a profession is facing in the new millennia. The book builds on the original work by Zelizer (1992) but expands and updates the debate and concept. Thus, the book illustrates the many ways that 'critical incidents' can manifest themselves in today's media landscape, such as when international journalists cover genocide (Magdenga, 2021) or the use of children as news sources (Sybert, 2021). This article builds on studies looking at critical incidents as part of paradigm repair research focusing on journalistic 'misdeeds' and 'ethical lapses' (Bennett et al., 1985; D'Angelo, 2021). However, we categorize journalistic misdeeds and ethical lapses under the theoretical headline of scandal research.

Today, scandals have become a frequent and prevalent part of modern societies (Pollack et al., 2018; Tumber \& Waisbord, 2019). Probably still, most prominent is the political scandal and the media coverage thereof, which are often the focus of scandal research (Entman, 2012; Pollack et al., 2018). The second focus in scandal research, however, are studies that focus on the corporate scandal, or the CEO scandal, where it is the media's coverage of the wrongdoing of big corporations or their CEOs that are in focus (Kuhn \& Lee, 2003; Benediktsson, 2010; Kantola, 2014). The third focus in media research concerning scandals is the victim's perspective (Karlsen \& Duckert, 2017; Hammarlin, 2019), while a fourth and final focus is the missteps and wrongdoings of journalists and the news media (Carlson, 2014; Carlson \& Berkowitz, 2014; Fenton, 2019). This article seeks to contribute, first, theoretically, by linking the understanding of critical incidents to the study and concept of the scandal. Second, empirically, by analyzing how different types of news media scandals lead to critical incidents, causing intense public debate about journalism's 'hows and whys.'

The article proceeds in the following steps to accomplish the goals above. First, the article argues that the use of Thompson scandal theory complements the existing research of critical incidents with a focus on journalistic misdeeds or ethical lapses in several ways: It 
helps to define, and thus identify, which events can be considered scandalous, and it helps to explain the relationship between scandal and power-in this case, the power of the news media. In turn, this helps explain why scandals themselves can be so powerful and have, sometimes, such severe consequences for the actors or institutions involved. Second, the article analyses two specific types of media scandals-the fabrication scandal and the erroneous information scandal-and shows precisely how news media scandals function as critical incidents that bring into question fundamental 'hows and whys' of journalism.

In this study, this means questioning ideals such as 'telling the truth' and practices such as basing stories on 'facts.' Still, the analysis of these scandals also shows that the scandals lead to specific reflections on 1) the increased competition between news media, 2) the pressure to produce more stories inside the individual newsroom, 3) the drive to get a 'scoop,' 4) journalism's relationship to powerful, as well as anonymous sources, and 5) the problems of a 'trust, not supervise' culture in the newsroom. However, while both types of scandals lead to reflections on journalism, this reflection stops when, in the case of fabrication scandals, the responsible reporter has been punished, usually by being fired, or, in the case of the erroneous information scandal, when the scandal has been 'handled' or when the scandal no longer receives media attention. Collectively, therefore, it seems that very little reflection is going on, as each new scandal most often is presented and discussed without mention of previous scandals, and only one example of a scandal directly leading to a change in news media practice was uncovered.

\section{News media scandals and the increased visibility of power}

Research-wise, what this article deems 'news media scandals' has been previously researched under different headlines. Often, cases of journalistic misconduct have been analyzed based on paradigm repair theory with a focus on how the news media caught in a scandal have tried to reestablish faith and legitimacy to the journalistic paradigm after the fact (Cecil, 2002; Hindman, 2005). Studies have also focused on journalistic transgressions as a question of journalistic boundary-crossing or journalistic deviance and analyzed 
how media discourse has set the boundaries between what can be defined as journalism or otherwise (Carlsson \& Berkowitz, 2014; Carlsson, 2014). On the other hand, other studies have focused on the concept of 'deceptive journalism' or 'journalistic deceptions' (Govaret et al. 2020, Lasorsa \& Dai, 2007). In these studies, the characteristics of so-called deceptive news stories are investigated based on the assumption that deceptive news stories have several common characteristics that can be used to identify and analyze these kinds of stories (Lasorsa \& Dai, 2007). In a recent German study, news media scandals were linked to journalistic norms and the increasing number of complaints to the German Press Council, indicating that these norms are declining amongst (some) German journalists (Kepplinger \& Viererbl, 2021).

As evident from the above, studies of news media scandals address the issue from various points of view. A way for research to more collectively address news media scandals would be to link their study closer to studies of other types of scandals, such as the political scandal (Thompson, 2000). For Thompson (2000, 2005), whose work was central in placing the political scandal as an important part of postmodern society, the growing prevalence of scandals in society is linked to the rise of a new and mediated visibility. This new visibility is again linked to the question of power. In earlier societies, before the existence of print media, television, and other types of media, the elites in power were largely invisible to regular citizens. Like kings or queens, when the elites did appear, it was for a restricted public, such as the nobles within the court (Thompson, 2005). This kind of visibility required co-presence and was also governed by law and strict social norms. With the rise of print media, television, and the internet, this all has changed. This change has led to the rise of the new kind of mediated visibility, where political leaders and other powerful elites become increasingly visible, sometimes by choice, at other times through leeks, paparazzi photos, or other types of visual or audio communication (Thompson, 2005; Trottier, 2018).

According to Thompson (2005), the rise of a new mediated visibility is a double-edged sword for those in power. On the one hand, the new visibility may be used to spread and control information, messages, and images; on the other hand, the new visibility can be a risk and lead to loss of control and to the exposure of secrets or information that may end up threatening those in power. Thus, for Thompson 
(2005), the rise of political scandals in postmodern societies is inexplicitly linked to a new mediated visibility most typically exemplified by the news media and investigative journalism. Thompson also clarifies the basic premise of most political scandals: making visible something previously hidden or invisible. All in all, Thompson (2000: 13-14) identifies five features of scandal: (1) transgressions of certain norms or values that, (2) were intended to remain concealed but become known to others, (3) who disapprove of these transgressions, (4) publicly express this disapproval, and (5) may damage the reputation of those involved.

In Thompson's view, scandals are linked to questions of power and holding the powerful elites, the political elite, and other kinds of power elites of society accountable. As studies about corporate, financial, or military scandals show, elites can be held accountable (Tumber \& Waisbord, 2019). Indeed, another kind of power elite that seems to be gaining more scandal attention, though so far perhaps mostly in public discourse, are journalists and news media owners. As mentioned, the news media scandal has previously been the subject of research. Still, this research has often been based on paradigm repair theory, where the focus is not so much the scandal itself but more on how the affected news media try to rebuild trust in their brands afterward (Hindman, 2005). However, as Fenton (2019) states, the study of scandal is as much a study of society's power elites as a study of ritual or journalistic ideals. Moreover, the news media and its leading journalists are themselves one such elite.

Though it is common to refer to the news media as powerful, as agenda-setters, or as the Fourth Estate, the study of journalists and news media as a power elite is much less common (Mayerhöffer \& Pfetsch, 2018; Fenton, 2019). Traditional elite theory is not blind to the existence of the news media, of course, but tends to view the news media as either in opposition to the traditional elites or to focus just on media owners or leading editors as elite members (Mayerhöffer \& Pfetsch, 2018). Consequently, when compared to the study of political elites or business elites, the study of media elites is much less common. There is, however, good reason to focus on media elites as they can, at least partially, control and influence the flow of news and information to society, while they also interact with, and sometimes influence, other power elites (Mayerhöffer \& Pfetsch, 2018; Fenton, 2019). Not only can journalists and the news media be seen as a 
power elite themselves, but the practices of this power elite, despite its focus on the transparency of political power, are often hidden and invisible from the common news consumer (Karlsson, 2011). Indeed, theory on transparency has long argued that viewed from the outside, 'news' seems to be produced in a black box shrouded in the mystery of objectivity. Karlsson (2011: 283) sums up this view of news production: News is produced inside a closed 'fortress newsroom' where journalists 'do' journalism based on routines that are invisible to the audience, and when the news product is finished, it falls out of a black box and appears before the audience. Based on the backstage/front stage dichotomy, Karlsson (2011) argues that most of the production of news - the gathering of information, the research, the talking to the sources, the priorities of the news desk, the editing, etc.-all take place backstage. From a transparency point of view, the problem for journalism is that its 'power' comes from journalists' and news organizations' historical claim of objectively and factually producing information based on a paradigm of objectivity; therefore, the news produced can be trusted by the audience (Karlsson, 2011). However, news production takes place almost entirely backstage and is mostly invisible, making journalism a hidden and almost archaic power form viewed from Thompson's (2005) argument about the invisibility or visibility of power. Based on this, it is easy to understand how news media scandals become global news stories, given that most of them bring visibility to highly questionable, unethical, or outright illegal practices of the media elite.

\section{News media scandals and what they reveal about 'the hows and whys' of journalism}

The very basis of the media's power comes from its assumed objectivity, which is, in itself, threatened by the invisibility of newsroom practices. One such practice is plagiarism, which is at the root of several news media scandals (Lewis \& Zhong, 2013). Here, studies suggest that a lack of clear rules on attribution in many newsrooms makes it difficult for reporters to draw a clear line between attribution and plagiarism (Hartley, Wittchen, \& Blach-Ørsten, 2020). However, studies also suggest that news media are reluctant to impose such rules and thus often leave it up to reporters to make up their own 
rules in this area. These rules may then vary from reporter to reporter, with some reporters more likely to consider attribution optional if under pressure to produce or if the creator of the original content was considered to be less experienced (Lewis \& Zhong, 2013). The pressure to produce content might also be the reason newsrooms resist firm rules on attribution or are hesitant to introduce practices where editors fact check their reporter's content (Blach-Ørsten, Hartley, \& Wittchen, 2018).

Other practices often leading to news media scandals are the practices of deception and fabrication. In one study by Lasorsa \& Dai (2007), the focus was on journalistic deceptions from 1998 to 2004. They found that different types of fabrication, such as 'source fabrication,' 'fact fabrication,' 'quote fabrication,' or 'full fabrication' accounted for most of the deceptive news while also finding many examples of plagiarism. They conclude, amongst other things, that the deceptions were possible because warning signs, such as a reporter with a high rate of corrections, were not communicated from newsroom to newsroom between organizations; that relationships between editors and reporters were built on trust without supervision; and that a lack of reporting standards and clear rules made reporters make up rules of their own (Lasorsa \& Dai, 2007).

Taken together, the studies on news media scandals caused by plagiarism, deception, and fabrication all point to hard questions about the 'how's and whys' of journalism. Some point to the pressure to produce content; some point to a morally 'flexible' newsroom culture when it comes to following ethical rules and other types of guidelines; others again point to a lack of clarity in both newsroom policies and professional codes. In sum, news media scandals question core ideals, values, and practices such as 'telling the truth,' 'being objective,' producing 'original reporting,' and basing stories on 'facts.' While studies show that some news media scandals lead to debate and reflection on newsroom practices, others point to an overall lack of willingness to more potently address these issues, especially from inside the newsroom (Kepplinger \& Viererbl, 2021). 


\section{Research setting and methodology}

The present work studies news media scandals using Denmark as a case study. Denmark is part of the democratic corporatist media system, emphasizing public service and private news media subsidies (Blach-Ørsten \& Willig, 2016). Despite recent changes caused by increased commercialization and digitalization, the Danish media system remains robust, with a high degree of traditional media use by most Danes and an above-average willingness to pay for news (Schrøder et al., 2020). Studies of news media scandals suggest that competition and shifting journalistic norms are attributed to a rising number of news media scandals (Kepplinger \& Viererbl, 2021). Though Danish news media remain robust despite increased commercialization and digitalization, studies of Danish news media also suggest that competition is on the rise (Allern et al., 2021) and that fewer reporters produce more news stories (Blach-Ørsten, 2013). However, studies on media ethics also show a high degree of compliance amongst journalists and new media organizations (BlachØrsten \& Lund, 2015), while also showing a relatively stable number of complaints to the Danish Press Council from 1999 to 2019 (BlachØrsten, Wittchen \& Hartley, 2021).

The starting year for the analysis is 2004, with the Frank Esmanplagiarism scandal. Though the first scandal in Denmark does not involve a reporter, referring to plagiarism in a book rather than a news report, the scandal set a new public and political agenda on the subject. Also, it led to new and more precise rules on what constitutes plagiarism by the Danish Ministry of Culture in $2006^{1}$. In other words, this scandal helped to open up journalists and, by extension, the news media to public scrutiny in a new way. This is important because a challenge when researching news media scandals is the fact that despite notable exceptions, they often receive little attention from the news media themselves, who may fear that reporting about scandals in other news media could damage their own news media's reputation or be seen as an attack on competitors (Kepplinger \& Viererbl, 2021). This is not helpful because meta-journalism, journalism about journalism, only plays a small role in many countries, Denmark included (Blach-Ørsten, Hartley \& Flensburg, 2018). All in all, this presents a fundamental challenge to the study of media scandals, which we will return to later. 
As the first step to this study, we constructed a list of news media scandals based on previous studies. This list consisted of four types of media scandals: 'fabrication scandals,' 'plagiarism scandals,' erroneous-information scandals,' and 'the hacking scandal.' When categorizing the scandals, we used Thompson (2000), characterizing the incidents according to what was criticized, made scandalous, in each incident, and which journalistic norms or values were supposed to stay hidden from the public. Like Lasorsa \& Dai (2007), we then sought out the potential scandals using databases, specifically Infomedia, which holds the largest database of Danish newspaper (online and paper) articles. Inspired by criteria developed in previous studies of scandals in Danish news media (Allern et al., 2012; Pollack et al., 2018), we focused on the mention of search words separately and together in different search strings. These search words included but were not limited to: 'scandal,' 'journalist,' 'news media,' 'news,' 'media organizations,' 'criticism,' 'correction,' 'press council.' 'journalism ethics,' 'sound press ethics,' 'fired,' or 'let go.' The names of the leading Danish news media were also included as search words. A separate search in the magazine Journalisten, the Danish Union of Journalists' magazine, was also conducted using the same search words and search strings. Finally, the same search words were used as the basis of a Google search to catch the coverage of the scandals in news media or magazines not found in the Infomedia database. Like Allern et al. (2012:31) a requirement for a case to be registered as a scandal is that the case has been reported as 'scandalous' by the news media. However, unlike Allern et al. (2012) we did not require a scandal to be reported by a specific number of news media or for a specific period of time. The reason for this is the aforementioned limited amount of meta-journalistic coverage in the news media. A good deal of the scandals uncovered by this study did receive substantial coverage in national news media, but other scandals were only covered by more niche-oriented media.

Using these search words, 19 news media scandals from 2004 to 2021 were identified and listed. These 19 news media scandals consisted of seven fabrication scandals, six erroneous information scandals, five plagiarism scandals, and one hacking scandal. An important caveat is, however, the aforementioned lack of 'journalism about journalism'. It is thus likely that the 19 news media scandals that we did uncover are not a complete list of news media scandals men- 
tioned in Danish news media from 2004 to 2021, but only a list of the most covered, high-profile scandals (see also Lasorsa \& Dai, 2007: 164).

Having already written extensively on plagiarism in a Danish context (Blach-Ørsten, Hartley, \& Wittchen, 2018; Hartley, Wittchen, \& Blach-Ørsten, 2020), we focused on two other types of prominent news media scandals in this study: the fabrication scandal and the erroneous information scandal. We analyze these scandals based on the following RQ:

RQ 1: Which type of debate, criticism, and reflections about 'the hows and whys of journalism' did the coverage of the fabrication scandals and the erroneous information scandals from 2004 to 2021 cause in the Danish news media?

\section{Analysis}

In the following, we first analyze how the fabrication scandal raises serious questions about journalism's relationship to 'the truth.' We then analyze the erroneous information scandal and how this type of scandal questions the journalism practice of basing stories on 'facts.'

\section{Questioning 'truth': The 'fabrication' scandal—when parts of stories or entire stories are made up}

In our material, the fabrication scandal is the most common type of news media scandal. It is also probably the most well-known type of news media scandal, as it aligns with the scandals made famous by Stephen Glass and Jayson Blair.

In 2005, Danish viewers of public service station $T V 2$ evening news bulletin learned that a heavily armed gang called Triple-A wanted to "take over fucking Zealand, Copenhagen. All of Denmark" $\left(\right.$ Politiken $\left.^{2}\right)$. However, it later turned out that there was no such gang. The fabrication resulted from $T V 2$ 's focus on gangs and a production company that was using young people for a promotional video to brand a new clothing company. TV 2 somehow used the tape made for the music video as a part of a larger story on gangs and violence in Denmark. Politicians and police started investigating the gang, but soon the young people from the video withdrew the quotes, which 
were made up as a "joke," and the police concluded that no gang named Triple-A existed. This led to massive criticism of $T V 2$, and the editor of $T V 2$ news was given a new position in the organization due to the scandal. At first, $T V 2$ denied the accusations, but after four weeks, mounting evidence, and public and political criticism, they withdrew the story and apologized ${ }^{3}$. The then-existing free newspaper, Urban, broke the story ${ }^{4}$. Still, it was also covered by an extended range of other news media, such as tabloid Ekstra Bladet, broadsheet Berlingske, and the business newspaper Børsen.

In 2007, the second public service channel in Denmark, Denmark's Radio $(D R)$, was heavily critiqued for telling the story of how Danish troops were leaving Iraq, while the images of the truck used as footage were actually going into Iraq. The foreign correspondent, Jeppe Nybroe, was responsible for the story. The fabrication was uncovered by the editor of the then-existing free newspaper, Nyhedavisen, and featured in the evening bulletin of $T V 2$. The scandal led to massive criticism of DR in the Danish Press, and Nybroe resigned. DR's ombudsman also carried out an internal investigation of Nybroe but found no other fabrications ${ }^{5}$. The story was also covered by other news media such as the broadsheet paper Jyllands-Posten, the tabloid newspaper Ekstra Bladet, and the regional newspaper Nordjyske.

In 2011, the Danish Magazine Journalisten ${ }^{6}$ uncovered that a free- $^{-}$ lance journalist working for Information as a correspondent in the UK had quoted a police chief who died in 2006. The correspondent, Mads Qvortrup, had also quoted other sources, who denied ever having spoken to the Danish journalist. The story was also covered by larger news media such as public service media, DR, the broadsheet newspaper Politiken, and the online magazine Mediawatch. However, no internal investigation was carried out, and the journalist resigned from Information, explaining that he was not a trained journalist but an academic. Therefore, he did not know the rules and norms of quoting in journalism. Reporting done by Journalisten suggested that internal sources had made the editor-in-chief aware of the problem. However, the then editor in chief said that the scandal was due to "sloppiness"' on the part of the reporter and that it was an internal matter that had been handled?

In 2014, the sports reporter Michael Qureshi (MQ) was accused of fabrication while working for the tabloid newspaper Ekstra Bladet. The newspaper had to withdraw an interview he had made with a 
famous football player. This was done relatively quietly, but a television sports program found the withdrawal of the interview so curious that they started their own investigation of MQ. On December 2, 2015, the program documented that MQ had used fake sources in his previous work; both quotes from sources he had never talked to and sources whose existence could not be verified by other reporters ${ }^{8}$. The scandal that also affected MQ's former places of employment, another tabloid newspaper, $B T$, and a sports magazine, was covered on and off until September 8, 2016, when the Danish police dropped the criminal investigation into MQ's reporting (see also Blach-Ørsten et al., 2018; Hartley et al., 2021).

In the spring of 2016, $\mathrm{Her}$ og $\mathrm{Nu}$, a weekly gossip magazine, published a story saying that the Danish crown prince secretly had sex with prostitutes and that this had gone for years. As a source, they quoted a Danish writer and sexologist who, in an interview with the magazine, had said a book he had written as fiction about a prostitute who had sex with someone from the Danish royal family, in reality, was based on a true story involving the crown prince. However, as soon as Journalisten ${ }^{9}$, the magazine of the Danish Union of Journalists, started investigating the story and claimed that it conflicted with the guiding rules of press ethics, the source retracted everything and said that all the quotes in the magazine where he pointed to the fact the crown prince had sex with prostitutes were pure fabrications made up by the magazine. The magazine's chief editor first claimed to stand by the story but was quickly let go by the publishers, who also retracted and apologized for the story.

In August 2019, one of the leading Danish newspapers, JyllandsPosten, fired a cultural reporter and their cultural editor. This was because the reporter wanted the paper to cover an exhibition he was involved with as an artist. The paper refused to do this due to a lack of resources. The reporter then interviewed himself as an artist and put another reporter's name on the interview. The fabrication was discovered by the cultural editor, who at first reprimanded the reporter. However, the editor failed to inform the chief editor of the reporter's wrongdoing, and consequently, both the reporter and the editor were let go from their positions. The story was uncovered by the culture magazine $E k k o^{10}$ and was also covered by the news site Mediawatch. 
In January of 2021, $D R$ broke a story about freelance photographer Michael Fonsmark, who throughout his career had staged and fabricated events that he either filmed or photographed and then sold to various news media. The most famous of these fabrications took place in 1998 when he sawed off the head of the statue of The Little Mermaid in Copenhagen and then sold his exclusive photos of the event to the news media. Even though most of the fabrications by Fonsmark had happened years earlier, $D R$ said in a statement from January 2021 that they would introduce new guidelines concerning acquiring pictures or videos from external suppliers as a consequence of the scandal. It was $D R$ who broke the story even though $D R$ was also involved in the case ${ }^{11}$.

\section{Crossing a line that cannot be crossed}

Taken together, it is evident by the brief summations above that there is a line that cannot be crossed and that crossing it has severe consequences for the reporters or others involved. The public criticism is also severe, even from within the newsroom. In the case of $T V 2$ and the Triple-A scandal, the board of $T V 2$ criticized the story publically, saying it had damaged the credibility of the TV station and underlining that such mistakes cannot be repeated (Politiken ${ }^{12}$ ). The then-head news editor of TV 2, Michael Dyrby, also publicly conceded that the story had damaged the image of the $T V 2$ station in the eyes of the public ${ }^{13}$. In the case of Jeppe Nybroe, the then news editor of DR, Ulrik Haagerup, also said in response to the scandal: " $I$ take this matter very seriously. Credibility is essential to DR and this cannot happen again ${ }^{14}(\ldots)$." In the case of Michael Qureshi, Ekstra Bladet went on a communication offensive, holding press meetings and talking extensively to other news media about the case, explaining and apologizing for the manipulation ${ }^{15}$. And in the 2021 case concerning the fabrications of Michael Fonsmark, it was $D R$ who broke the story even though $D R$ was also involved in the case. This helped $D R$ take control of the story and be the first to apologize for using Fonsmark, even though his staged work had also conned other news media throughout the years.

There had been clear warning signs beforehand in many of the scandals, mostly from other reporters within the newsroom, warning of the stories done by Jeppe Nybore or Michael Qureshi. Still, 
these warning signs were either overlooked or never made it to the responsible editors. Finally, in many cases, the news media choose to present the scandals as the works of a few 'bad apples' (Cecil, 2002; Ogbebor, 2020), who were then either let go or demoted a solution to the problem. Most news media did not deny the accusation once they were made public, with $T V 2$ and Triple-A as an exception: both the editor responsible for the story and the head of the News section wrote a lengthy defense of the story before eventually retracting it $^{16}$. If the scandals led to any change inside the new organizations involved in the fabrication scandals, this remains only vague from the media coverage. Thus, as a response to the Jeppe Nybroe scandal, the then head of $D R$ News stated that: "In DR News we have learned a lot from the case ${ }^{17}(\ldots)$ " and the head of $T V 2$ news said that the story of TripleA had made them reconsider how they present stories and as well as reconsider the risk of oversimplifying stories ${ }^{18}$.

Altogether, the seven fabrication scandals led editors, politicians, and experts to reflect on several essential 'hows and whys' of journalism, such as the pressure to produce more stories inside the individual newsroom, the drive to get a scoop, as well as on the problems of a 'trust, not supervise' culture in the newsroom.

\section{Questioning the 'facts': When stories, either deliberately or by accident, are based on erroneous information}

With six scandals falling into this category, this is the second most common type of high-profile news media scandal uncovered in our material.

In 2008 and 2009, a political scandal known as the 'Special Forces book scandal' broke in the Danish news media. The scandal concerned a former soldier who had served in the Danish Special Forces, who wrote a book about his experiences. The Minister of Defense and the Department of defense labeled the book a threat to national security and wanted it redrawn from the book market (Blach-Ørsten, 2011). As an argument supporting the fact that the book was a national threat, the defense minister stated that a translation of the book into Arabic was already available on the net. The tabloid newspaper $B T$ published a link to this supposed translation shortly after that. However, the newspaper quickly removed the link, claiming that the translation was nonsensical. At the same time, it was revealed that 
an insider from the Danish Defense Command translated the document ${ }^{19}$. All leading news media covered the case in Denmark. It was later revealed that $B T$ got the translated book from the Defense Command, though the editor responsible at $B T$ defined this at first, stating he found the translation online ${ }^{20}$, only later to change his statement to Politiken, and say that he was not so sure, if and where he saw the book $^{21}$. In the end, the scandal had no consequences for BT or the responsible editor.

In 2010, following several weeks of coverage of the "Maria-murder $^{22}$," the brutal murder of a twenty-year-old young woman in the city of Herning in Jutland, readers woke up to the front page of Danish tabloid Ekstra Bladet showcasing a large picture of an unknown citizen of Herning named Jan Lindholdt Mikkelsen. Ekstra Bladet publicized that he was charged with the murder. Mikkelsen spent 18 days in custody until DNA cleared him of all suspicions. The accused was so distressed by the wrongful accusation and being on the front page that he considered suicide while in prison. Because his lawyer had failed to ask for protection of his identity, Ekstra Bladet did not violate any ethical rules by placing Lindholdt Mikkelsen on the front page; this was met by massive criticism by the public and politicians alike $^{23}$, with the politicians using the scandal as a reason for revisiting the Media Responsibility Act $^{24}$ (see also Blach-Ørsten \& Lund, 2015). In the end, the editor-in-chief apologized but also underlined that the newspaper hadn't violated ethical rules in the process of covering the story. The scandal also led to a significant debate on the amount given in compensation to victims of journalistic scandals, as Jan Lindholdt Mikkelsen received just 37.000 KR.

In 2013, $D R$ ran a story based on a local and regional election exit poll. The Exit poll claimed that the Social Democratic Party would suffer a severe setback, and DR began to run more stories based on this scenario. The exit poll, however, got the result completely wrong. The Social Democrats had a very good election and maintained their position as the biggest party, regionally and locally. The story started with a massive critique of $D R^{25}$ and fellow public broadcaster TV 2 for their use of exit polls and their failure to take the statistics uncertainness of such polls into account.

Consequently, $D R$ apologized ${ }^{26}$ and changed their practice using exit polls so that $D R$ can be more careful using, and sometimes not using, exit polls in their election coverage ${ }^{27}$. Much other news media 
expressed similar concerns regarding the use of exit polls. DR's ombudsman also delivered severe criticism on the use of exit polls ${ }^{28}$.

In 2014, the newspaper Politiken wrote on the front page that the current Prime Minister Lars Løkke Rasmussen was resigning ${ }^{29}$. The information came from what the political editor called a "good source;" however, this was not true. The editor-in-chief of Politiken, Bo Lidegaard, gave several interviews apologizing for the story ${ }^{30}$. The incident had no consequences for staff, and Lidegaard did not resign but promised to make sure that the credibility of Politiken would be rebuilt and that they would have to consider all stories based on anonymous sources very carefully in the future. Though Politiken caught most of the flack on the story, similar and sometimes identical stories of Løkke's possible resignation were also reported by other news media, including Berlingske, Jyllands-Posten, and Børsen ${ }^{31}$, stories for which they also apologized ${ }^{32}$.

In 2018, the newspaper Jyllands-Posten ${ }^{33}$ published a story online that, in large parts, was based on a story from Austrian tabloid newspaper Kronen Zeitung. The story claimed that 20,000 immigrants were waiting at the border of the EU and that most of them were armed with knives. The Independent Danish news site, Altinget $t^{34}$, ran the story and uncovered no independent documentation for the claims in the Jyllands-Posten's version of the story. Jyllands-Posten, however, stood by their article ${ }^{35}$ and also defended it in an article on Altinget ${ }^{36}$. The facts of the story were later debunked ${ }^{37}$. Jyllands-Posten then ran a correction of the story but did not retract it.

In 2021, right up to an election in Greenland, public service station $T V 2$ published a story alleging that the leading candidate, Múte Egede, had attended meetings that could have positively affected his personal finances through a company he owned ${ }^{38}$. The candidate immediately contacted $T V 2$ and told them that the story was wrong, but it took $T V 2$ two days to acknowledge this and correct the article $^{39}$. The tabloid newspaper, Ekstra Bladet, then uncovered that the reporters, who put their name on the story, had tried to get out of writing the story because they could not get the facts in the story verified. They were, however, pressured by an editor to publish the story anyway $^{40}$. This editor then chooses to resign from $T V 2$, saying she had failed when she pushed the story ${ }^{41}$. TV 2 has since apologized for the story ${ }^{42}$, but this has not brought a close to the story or the question of how a story with no facts got published by a leading public 
service news media like $T V 2$, a question that the Danish minister for culture also wants answered ${ }^{43}$, as does the newly elected government in Greenland, which Múte Egede, the falsely accused candidate, is now heading ${ }^{44}$.

\section{Negotiating the 'facts'}

Getting the facts wrong is a severe problem for news media, especially if these erroneous facts involve politics or politicians, as was the case with the erroneous stories on then Prime Minister Lars Løkke Rasmussen from politics, the unreliable exit polls used to cover the regional and local elections, and the case about the election in Greeland and Múte Egede. Looking at the consequences for the reporters and news media involved, however, getting the facts wrong is not as bad as making up the facts altogether. So while the news media scandals concerning erroneous led to a good deal of criticism and self-reflection, they did not lead to reporters being fired for their mistakes, as was the case with some of the fabrication scandals. An exception here is TV 2 and the erroneous story on Mute Egede, where the responsible editor resigned. It is, however, also possible for news media to 'negotiate' the facts, as Jyllands-Posten tried to do in the story from Kronen Zeitung. Here, Jyllands-Posten, for a long time, referred back to the original source in Austria and the Austrian government. However, a lot of evidence suggested that the 'facts' Jyllands-Posten had based their story on were not verified. Altogether, the six erroneous information scandals led editors, politicians, and experts to some of the same types of reflections as was evident from the fabrication scandals, such as the news media's drive to get a 'scoop,' its relationship to anonymous sources ${ }^{45}$, as well as the problems of a 'trust, not supervise' culture in the newsroom.

\section{Discussion and Conclusion}

The purpose of this article has been twofold: first, theoretically, to link this understanding of critical incidents to the study and theory of the scandal. Second empirically, to analyze how different types of news media scandals lead to reflection and debate about the standards and practices of journalism. We have thus tried to answer the 
following RQ: Which type of debate, criticism, and reflections about 'the hows and whys' of journalism did the coverage of the fabrication scandals and the erroneous information scandals from 2004 to 2021 cause in Danish news media?

Though less covered than political scandals, our analysis of the two types of news media scandals clearly shows that the scandals lead to public criticism and reflections about 'the hows and whys' of journalism. Taken together, we find the two types of media scandals lead to serious questions about some of the fundamental 'hows and whys' of journalism, such as journalism's relationship to 'telling the truth,' 'reporting objectively,' and basing stories on 'facts.' We also find that crossing the line between news and fabrication often has severe consequences, though mainly for the individual reporters, rather than the news organizations involved. Getting the 'facts' wrong also has consequences, but they are far from as severe as fabrication scandals.

Concerning reflections, we further find that the scandals lead news media and editors to reflect on 1 ) the increased competition between news media, 2) the pressure to produce more stories inside the induvial newsroom, and 3) the drive to get an exclusive 'scoop.' This is evident from scandals such as the Qureshi scandal, the scandal about Lars Løkkes' 'fake' resignation and the Exit-poll scandal. News media scandals have also led editors to reflect on; 4) journalism relationship to powerful and or anonymous sources, such as in the scandal about the 'Special Service-book,' for instance, in Lars Løkke's fake resignation, and, most recently, in TV 2's 'Greenland-scandal.' Finally, the news media scandals covered in this article have led to reflections on 5) the problems of a 'trust, not supervise' culture in the newsroom, which comes up with the Qureshi scandal and Jeppe Nybroe scandal.

The news media scandals have also led to a higher awareness amongst editors as to the need to maintain credibility and trust, which has been evident in the editorial response to a good deal of the scandals and has also been used as an argument for sanctioning or firing the scandalized reporters. However, most of the scandals seem to be 'solved' by the news media apologizing and promising to do better in the future. Outside the news media, the scandals have had general consequences for the Danish media system: some have fueled political demands for more control of the news media and new and stricter guidelines for the news media. Indeed, the general guidelines for press ethics in Denmark were updated in 2013 as 
a direct consequence of some of the news media scandals featured in this article (see also Blach-Ørsten \& Lund, 2015).

In sum, the increased visibility that the news media have brought about, according to Thompson (2000), has also increased the visibility of news media organizations themselves. This is especially true in the critical incidents that we have examined in this article, where the visibility caused by news media scandals has brought light to highly questionable journalistic and news media practices, as well as raising serious questions about journalists' and news organizations' historical claim that they produce objective and factual information. The news media scandals caused by fabrication or erroneous information point to blind spots inside the 'black box' of the newsroom's 'fortress.' The control and fact-checking of information that is an essential mission for modern journalism is sometimes lacking when it concerns the 'inside' control of the information being produced by the news media themselves.

It is also interesting to note that while journalists and news media themselves have actively engaged in the debate about several of the news media scandals mentioned here, they almost always do so referring to the scandals in a journalistic discourse highlighting professionalism and ethical rules, and most often casting blame on a few bad apples. And all through the scandals have led to a lot of reflection on behalf of the news media, they seem to have led to little observable change in news media practice, with the revised use, or not use, of exit polls as perhaps the only example of a scandal directly leading to changed practice.

\section{NOTES}

1 https://kum.dk/fileadmin/_kum/5_Publikationer/2006/God_citatskik_ og_plagiat_i_tekster.pdf

2 https://politiken.dk/kultur/art4873367/Historien-om-Triple-A).

3 https://journalisten.dk/skudt-ned/

4 https://ekstrabladet.dk/nyheder/samfund/article3054957.ece

5 https://www.dr.dk/nyheder/indland/dr-undersoegelse-rejser-ikke-yderligere-kritik-af-jeppe-nybroe

6 https://journalisten.dk/citatfusk-af-ukendt-omfang-pa-information/

https://mediawatch.dk/Medienyt/Aviser/article5177975.ece

${ }^{8}$ https://www.facebook.com/tv3sportsl/posts/her-kan-du-se-hele-ind- 
slaget-fra-onside-om-michael-qureshi/1669705546601121/

9 https://journalisten.dk/ekspert-hernu-bryder-loven-med-pastand-omkronprinsens-utroskab/

${ }^{10}$ https://www.ekkofilm.dk/artikler/kulturredaktor-fyret-efter-fup-interview/

${ }^{11}$ https://www.dr.dk/etik-og-rettelser/transparens/grundig-research-bagdr-dokumentar-om-kontroversiel-fotograf

${ }^{12}$ https://politiken.dk/kultur/art5698159/TV2-bestyrelse-Triple-A-sag-harskadet-vores-trov\%C3\%A6rdighed

${ }^{13}$ https://nyheder.tv2.dk/baggrund/article.php/id-2746272\%253Fteaser.

${ }^{14}$ https://www.dr.dk/om-dr/nyheder/dr-reagerer-paa-irak-indslag

${ }^{15}$ https://www.dr.dk/nyheder/kultur/medier/ekstra-bladets-chefredaktoer-omfanget-af-journalistisk-svindel-er-chokerende

${ }^{16}$ https://nyheder.tv2.dk/article.php/id-2693125.html

${ }_{17}$ https://www.dr.dk/nyheder/indland/dr-undersoegelse-rejser-ikke-yderligere-kritik-af-jeppe-nybroe

${ }^{18}$ https://nyheder.tv2.dk/baggrund/article.php/id-2746272\%253Fteaser

${ }^{19}$ https://www.bt.dk/politik/b.t.-chef-jeg-saa-jaegerbog-paa-nettet

${ }^{20}$ https://journalisten.dk/arets-historie/

${ }^{21}$ https://politiken.dk/indland/art4820371/B.T.-chef-\%C3\%A6ndrer-forklaring-om-j\%C3\%A6gerbog

${ }^{22}$ https://politiken.dk/indland/art4820371/B.T.-chef-\%C3\%A6ndrer-forklaring-om-j\%C3\%A6gerbog

${ }^{23}$ https://sn.dk/Danmark/Politikere-forargede-over-Ekstra-Bladet/arti$\mathrm{kel} / 41296$

${ }^{24}$ https://finans.dk/artikel/ECE4321628/Politikere:-EB-d\%C3\%A6kningkalder-p\%C3\%A5-stramninger/?ctxref=ext

${ }^{25}$ https://www.dr.dk/nyheder/politik/valg/kv13/brian-mikkelsen-kritiserer-dr-pilskaev-exitpoll

${ }^{26}$ https://www.dr.dk/nyheder/politik/valg/kv13/dr-beklager-forkerte-exitprognoser

${ }^{27}$ https://mediawatch.dk/Medienyt/TV/article7795380.ece

${ }^{28}$ https://www.dr.dk/etik-og-rettelser/brugernes-redaktoer/langt-tilloebtil-skandaloes-dr-prognose

${ }^{29}$ https://politiken.dk/indland/politik/art5607258/Politiskredakt\%C3\%B8r-L\%C3\%B8kke-tr\%C3\%A6kker-sig-i-aften

${ }^{30}$ https://politiken.dk/kultur/medier/art5519354/Politikenschefredakt\%C3\%B8r-beklager-forkerte-historier-om-L\%C3\%B8kkesafgang 
${ }^{31}$ https://www.berlingske.dk/samfund/medier-angrer-daekning-af-loekkes-afgoerende-dag

${ }^{32}$ https://www.dr.dk/nyheder/kultur/medier/medier-erkender-vi-har-fejlet-i-daekningen-af-loekke-sagen

${ }^{33}$ https://jyllands-posten.dk/international/ECE10991008/medie-oestrigadvarer-om-20000-migranter-paa-vej-ind-i-eu/

${ }^{34}$ https://www.altinget.dk/artikel/falsk-historie-rejste-verden-rundt-ogendte-i-jyllands-posten

35 https://mediawatch.dk/Medienyt/Aviser/article11076219.ece

${ }^{36}$ https://www.altinget.dk/artikel/jyllands-posten-irriterende-at-vi-ikkekan-dokumentere-historien

${ }^{37}$ https://www.altinget.dk/artikel/stoejberg-faar-jp-historie-afkraeftet-ioestrig

${ }^{38}$ https://nyheder.tv2.dk/politik/2021-04-02-groenlandsk-politiker-afviseranklager-og-tv-2-beklager

${ }^{39}$ https://www.berlingske.dk/kommentatorer/fejl-paa-fejl-i-tv-2-sag-erdybt-skadelige-for-den-kritiske-presse

${ }^{40}$ https://ekstrabladet.dk/nyheder/samfund/intern-mail-tre-journalisterpresset-i-tv-2-skandale/8638527

${ }^{41}$ https://piopio.dk/tv-2-redaktionschef-stopper-efter-haard-kritik

${ }^{42}$ https://omtv2.tv2.dk/nyheder/2021/06/tv-2s-direktoer-om-fejlagtig-artikel-vi-ser-paa-sagen-med-meget-stor-alvor/

${ }^{43}$ https://policywatch.dk/nyheder/christiansborg/article13114463.ece

${ }_{44}$ https://www.berlingske.dk/danmark/mute-egede-er-klar-til-at-politianmelde-tv2-for-falsk-historie

${ }^{45}$ https://www.dr.dk/nyheder/kultur/medier/medier-erkender-vi-har-fejlet-i-daekningen-af-loekke-sagen

\section{REFERENCES}

Allern, S., Blach-Ørsten, M., Kantola, A., \& Pollack, E. (2021). Development trends and challenges in Nordic political journalism. In E. Skogerbø, Ø. Ihlen, N. Nørgaard Kristensen, \& L. Nord (eds.), Power, Communication, and Politics in the Nordic Countries (pp. 135-154). Nordicom. https://doi. org/10.48335/9789188855299

Allern, S., Pollack, E., \& Kantaloa, A. \& Blach-Ørsten, M. (2012). Increased Scandalization: Nordic Political Scandals 1980-2010. I S. Allern, \& E. Pollack(eds.), Scandalous: The mediated construction of Political Scandals in four Nordic countries (p. 29-50). Nordicom. 
Benediktsson, M. O. (2010). The deviant organization and the bad apple CEO: Ideology and ac-countability in media coverage of corporate scandals. Social Forces, 88(5), 2189-2216. https://doi.org/10.1353/sof.2010.0032

Bennett, W. L., Gressett, L. A., \& Haltom, W. (1985). Repairing the news: A case study of the news paradigm. Journal of Communication. 35(2), 50-69. https:// doi.org/10.1111/j.1460-2466.1985.tb02233.x

Blach-Ørsten, M. (2013). The emergence of an increasingly competitive news regime in Denmark. In R. Kuhn \& R.K. Nielsen (eds.), Political journalism in transition: Western Europe in a comparative perspective (pp. 93-110). IB Tauris. https://doi.org/10.5040/9780755694723.ch-005

Blach-Ørsten, M. \& Lund, A. (2015). Troværdig journalistik - et spørgsmål om etik og nøjagtighed. (Credible Journalism - a question of ethics and accuracy). Samfundslitteratur.

Blach-Ørsten, M., \& Willig, I. (2016). Det danske mediesystem. (The Danish Media System). In T. Olesen (ed.), Medier, politik og samfund (pp. 13-34). Hans Reitzels Forlag.

Blach-Ørsten, M., Hartley, J. M., \& Wittchen, M. B. (2018). A Matter of Trust: Plagiarism, fake sources and paradigm repair in the Danish news media. Journalism Studies, 19(13), 1889-1898. https://doi.org/10.1080/14616 70X.2018.1492878

Blach-Ørsten, M., Bendix Wittchen, M., \& Møller Hartley, J. (2021). Ethics on the Beat: An Analysis of Ethical Breaches Across News Beats from 1999 to 2019. Journalism Practice, https://doi.org/10.1080/17512786.2021.1956363

Carlson, M. \& Berkowitz, D. (2014). The emperor lost his clothes: Rupert Murdoch, News of the World and journalistic boundary work in the UK and USA. Journalism, 15(4), 389-406. https://doi.org/10.1177/1464884913477280

Carlson, M. (2014). Gone, but not forgotten: Memories of journalistic deviance as metajournalistic discourse. Journalism Studies, 15(1), 33-47. https://doi. org/10.1080/1461670X.2013.790620

Cecil, M. (2002). Bad apples: Paradigm overhaul and the CNN/Time "Tailwind" story. Journal of Communication Inquiry, 26(1), 46-58. https://doi. org/10.1177/019685990202600104

Coddington, M. (2012). Defending a paradigm by patrolling a boundary: Two global newspapers' approach to WikiLeaks. Journalism \& Mass Communication Quarterly, 89(3), 377-396. https://doi.org/10.1177/1077699012447918 D'Angelo, P. (2021). Critical Incident as a construct in journalism studies. In E. C. Tandoc, J. Jenkins, R. J. Thomas, \& O. Westlund (eds.), Critical Incidents in Journalism. Pivotal Moments Re-shaping Journalism Around the World (pp.15-27). Routledge. https://doi.org/10.4324/9781003019688-3 
Djerf-Pierre, M. \& Shehata, A. (2017). Still an agenda setter: Traditional news media and public opinion during the transition from low to high choice media environments. Journal of Communica-tion, 67(5), 733-757. https:// doi.org/10.1111/jcom.12327

Entman, R. M. (2012). Scandal and silence: Media responses to presidential misconduct. Polity.

Fenton, N. (2019). The scandalous power of the press: Phone hacking in the U.K. In H. Tumber \& S. Waisbord. (eds.), The Routledge Companion to Media and Scandal (pp. 333-341). Routledge. https://doi.org/10.4324/978135117300134

Govaert, C., Lagerwerf, L., \& Klemm, C. (2020). Deceptive Journalism: Characteristics of Un-trustworthy News Items. Journalism Practice, 14(6), 697-713. https://doi.org/10.1080/17512786.2019.1637768

Hammarlin, M. M. (2019). Exposed: Living with scandal, rumor, and gossip. Lund University Press.

Hartley, J. M., Wittchen, M. B., \& Blach-Ørsten, M. (2020). Peeling or plagiarizing? A Danish media scandal as an incident of re-instating boundaries in the grey zones of "good" journalistic citing practices. In E. C. Tandoc, J. Jenkins, R. J. Thomas, \& O. Westlund (eds.), Critical Incidents of Journalism: Pivotal Moments Reshaping Journalism around the World (pp. 45-56). Routledge.

Hindman, E. B. (2005). Jayson Blair, The New York Times, and Paradigm Repair. Journal of Communication, 55(2), 225-241. https://doi.org/10.1093/ joc/55.2.225

Jenkins, J., Tandoc, E. C, Thomas, R. J., \& Westlund, O. (2021). Introduction. In E. C. Tandoc, J. Jenkins, R. J. Thomas, \& O. Westlund (eds.). Critical Incidents in Journalism. Pivotal Moments Reshaping Journalism Around the World (pp. 1-12). Routledge. https://doi.org/10.4324/9781003019688-1

Kantola, A. (2014). Mediatization of power: Corporate CEOs in flexible capitalism. Nordicom Review, 35(2), 29-41. https://doi.org/10.2478/nor-2014-0013

Karlsen, K. E. \& Duckert, F. (2017). Å være i medienes kritiske søkelys. Enkeltindividenes erfa-ringer. Norsk medietidsskrift, 24(03), 1-18. https://doi. org/10.18261/issn.0805-9535-2017-03-03

Karlsson, M. (2011). The immediacy of online news, thevisibility of journalistic processes and a restructuring of journalistic authority. Journalism, 12(3), 279295. https://doi.org/10.1177/1464884910388223

Kepplinger, H. M. \& Viererbl, B. (2021). Borderline journalism: Why do journalists accept and justify questionable practices that establish scandals? A quantitative survey. Journalism, 22(3), 650-670. https://doi. org/10.1177/1464884918801077 
Kuhn, T. \& Lee Ashcraft, K. (2003). Corporate scandal and the theory of the firm: Formulating the contributions of organizational communication studies. Management Communications Quarterly, 17(1), 20-57. https://doi. org/10.1177/0893318903253421

Lasorsa, D. L. \& Dai, J. (2007). Newsroom's Normal Accident? An exploratory study of 10 cases of journalistic deception. Journalism Practice, 1(2), 159-174. https://doi.org/10.1080/17512780701275473

Lewis, N. P. \& Zhong, B. (2013). The root of journalistic plagiarism: Contested attribution be-liefs. Journalism \& Mass Communication Quarterly, 90(1), 148-166. https://doi.org/10.1177/1077699012468743

Magdenga, F. (2021). (Re)telling the story. Is the Rwanda genocide acritical incident in journalism?. In E. C. Tandoc, J. Jenkins, R. J. Thomas, \& O. Westlund (eds.), Critical Incidents in Journalism. Pivotal Moments Reshaping Journalism Around the World (pp. 109-118). Routledge. https://doi. org/10.4324/9781003019688-11

Mayerhöffer, E. \& Pfetsch, B. (2018). Media Elites. In H. Best \& J. Higley (eds.), The Palgrave Handbook of Political Elites (pp. 417-437). Palgrave Macmillan, London. https://doi.org/10.1057/978-1-137-51904-7_27

Ogbebor, B. (2020). Paradigm Repair: Bad Apples and Self-Assertion. In B. Ogbebor (ed.), British Media Coverage of the Press Reform Debate (pp. 123-150). Palgrave Macmillan, Cham. https://doi.org/10.1007/978-3-030-37265-1_7

Pollack, E., Allern, S., Kantola, A., \& Blach-Ørsten, M. (2018). The New Normal: Scandals as a Standard Feature of Political Life in Nordic Countries. International Journal of Communication, 12. https://ijoc.org/index.php/ijoc/article/ view/7099/2417

Schrøder, K., Blach-Ørsten, M., \& Eberholst, M. K. (2020). Danskernes brug af nyhedsmedier. Center for Nyhedsforskning (News media use in Denmark). Roskilde Universitet. https://doi.org/10.5281/zenodo.4063341

Singer, J. B. (2005). The political j-blogger: 'Normalizing' a new media form to fit old norms and practices. Journalism, 6(2), 173-198. https://doi. org/10.1177/1464884905051009

Sybert, J. (2021). The voices of Aleppo: Re-evaluating US journalistic practices for news coverage of children during the Syrian Civil War. In E. C. Tandoc, J. Jenkins, R. J. Thomas, \& O. Westlund (eds.), Critical Incidents in Journalism. Pivotal Moments Reshaping Journalism Around the World (pp. 57-70). Routledge. https://doi.org/10.4324/9781003019688-7

Tandoc, E. C., Jenkins, J., Thomas, R. J., \& Westlund O. (eds.). (2021). Critical Incidents in Journalism. Pivotal Moments Reshaping Journalism Around the World. Routledge. https://doi.org/10.4324/9781003019688 
Thompson, J. B. (2000). Political scandal: Power and visibility in the media age. John Wiley \& Sons.

Thompson, J. B. (2005). The new visibility. Theory, culture \& society, 22(6), 31-51. https://doi.org/10.1177/0263276405059413

Thornton, B. (2000). The Moon Hoax: Debates About Ethics in 1835 New York Newspapers. Journal of Mass Media Ethics, 15:2, 89-100. https://doi. org/10.1207/S15327728JMME1502_3

Tumber, H. \& Waisbord, S. (eds.). (2019). The Routledge companion to media and scandal. Routledge. https://doi.org/10.4324/9781351173001

Trottier, D. (2018). Scandal mining: political nobodies and remediated visibility. Media, Culture \& Society, 40(6), 893-908. https://doi. org/10.1177/0163443717734408

Zelizer, B. (1992). CNN, the Gulf War, and Journalistic Practice. Journal of Communication, 42(1), 66-81. https://doi.org/10.1111/j.1460-2466.1992. tb00769.x

\section{MARK BLACH-ØRSTEN}

Professor

Department of Communication and Arts

Roskilde University

oersten@ruc.dk

\section{JANNIE MøLLER HARTLEY}

Associate Professor

Department of Communication and Arts

Roskilde University

jath@ruc.dk

\section{MARIA BENDIX WITTCHEN}

PhD Student and Teaching Associate Professor

Department of Communication and Arts

Roskilde University

mbendixw@ruc.dk

DOI: 10.7146/journalistica.v15i1.125395 